\title{
Henrik Wergeland om selvmord
}

v/ Lars M ehlum

Den sterke økningen i forekomst av selvmord i N orge fra slutten av 1960-tallet frem mot slutten av 1980-tallet er kjent for mange. Langt færre er klar over at nåtidens høye selvmordstall ikke er enestående i vårt lands historie. D ette blir tydelig dersom vi ser nærmere på landsdekkende epidemi ologiske data for sel vmordshyppigheten som $\mathrm{i} N$ orge starter med året 1826 ( $G$ jertsen 1987). På midten av 1800-tallet, særlig i perioden 1830-60, hadde $\mathrm{N}$ orge også forholdsvis høye selvmordsrater (11-12/100 000 pr år) (kvinner og menn under ett), langt høyere tall enn i hele hundreårsperioden mellom ca 1860 og 1960. Flere av samtidens fremtreden de fagfolk befattet seg med dette problemet, og blant dem er nok Eilert Sundt (1817-75) mest kjent. H ans bidrag til beskrivelse og forståelse av selvmordsproblematikken har vi omtalt i en tidligere artikkel i Suicidologi ( $M$ ortensen 1998). M indre kjent er det antakelig at vår store dikter $\mathrm{H}$ enrik W ergeland også interesserte seg for temaet, og det på et enda tidligere tidspunkt. W ergelands brede samfunnsengasjement er nok en viktig bakgrunn for denne interessen. $M$ en også på det personlige plan hadde han erfaringer som ga ham innsikt i selvmordsproblematikken. Etter å ha blitt ettertrykkelig avvist av en kvinne han i lengre tid hadde vært sterkt betatt av, gjorde han den 26. juli 1827 et alvorlig selvmordsforsøk han senere omtalte som "den skrekkeligste av alle hen delser". Sinnstilstanden han var i bar preg av dyp depresjon hvor psykosen kan ha vært nær. "Jeg var avsindig - o mer enn avsindig", skrev han om dette. I Y ngvar U stvedts W ergelandsbiografi (1994) er det gitt en detaljert og god beskrivelse av denne fasen i dikterens liv. Som vi skjønner har altså W ergeland hatt en personlig bakgrunn for sitt engasjement i temaet selvmord.

I dette nummeret av Suicidologi bringer vi $\mathrm{H}$ en rik W ergelands opplysningsskrift fra 1840 om selvmord. Skriftet er i dag interessant som et bidrag til historieskrivningen om selvmord i N orge. Samtidens holdninger til selvmord og selvmordsnære kan til en viss grad gi oss en pekepinn om viktige samfunnsmessige forh old. M en W ergelands skrift har ikke bare historisk interesse. Før vi slipper dikteren til skal vi kort peke på noen interessante poeng.

\section{Forståelse fremfor fordømmelse}

På W ergelands tid var den dominerende holdning at selvmord var naturstridig og dessuten en tilsidesettelse av plikten mot $G$ uds bud, mot fedrelandet og mot sl ekt og venner. For en "kold Betragter og O verveier" kan i følge W ergeland dette synes opplagt og overbevisende. M en for den som har mistet alt håp, er ikke disse motforestillingene al ltid i stand til å demme opp mot selvmordet. Her peker W ergeland på behovet for å forstå hvordan situasjonen kan oppleves for den selvmordsnære personen i stedet for å fordømme eller moralisere. Wergeland tilhører jo opplysningstiden med dens vektlegging av rasjonalitet. M en i denne sammenheng, som så ofte ellers, viser W ergeland seg som en uavhengig tenker gjennom sin understrekning av innlevelse og forståelse fremfor "kold" rasjonalitet. I dag vet vi hvor avgjørende empati er for vår evne til å være til hjelp for mennesker i selvmordskriser. W ergelands holdning slik den fremkommer i dette skriftet, representerer også en modig teologs brudd med datidens juridiske og religiøse sanksjoner mot selvmordsnære personer. På denne tiden var det fortsatt forbudt å gravlegge selvdrepte i kristen jord (forbudet ble opphevet i 1843). Likeledes var det forbudt med kristne seremonier ved gravlegging av selvmordere (opphevet først i 1897).

\section{"At utvide Haabets Grendser"}

W ergeland peker også på håpets sentrale betydning; "A t udvide $\mathrm{H}$ aabets $\mathrm{G}$ rendser maatte vel være det kraftigste $M$ iddel til at svække det O ndes Indtryk". M en hvordan skal så disse håpets grenser utvides? $\AA$ bli møtt med empati er faktisk en grunnleggende forutsetning - det later det til at W ergeland har innsett til fulle. $M$ en her viser han seg også fra en mer jordnær og pragmatisk side. $\mathrm{H}$ an diskuterer hvordan man kan styrke håpet ved å hjelpe den selvmordsnære til å se at vansker kan overvinnes, problemer kan løses og vonde følelser kan ta slutt. H er vil det være nyttig om mulig å trekke inn den enkeltes tidl igere vellykkede erfaringer med problemløsning. M ange psykoterapeuter vil kjenne igjen denne type intervensjonsstrategi. W ergeland argumenterer også

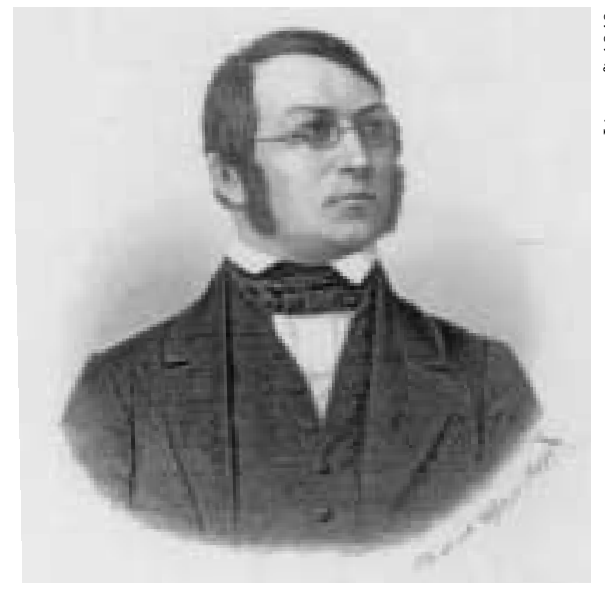

for at det alltid er for tidlig å ta sitt liv. "H vorfor overile sig? Dødens A rme staae jo altid aabne". M en her og nå finnes det som regel muligheter til å forbedre situasjonen, få det lettere, en bedre morgendag. W ergel ands tenkning viser også $i$ denne sammenheng slektskap med viktige retninger innen terapeutisk tilnærming til mennesker i suicidal kriser der vekten legges på problemløsningsstrategier og modifisering av fastlåste tankemønstre med mål om redusert hjelpeløshet og håpløshet.

M en nå er det på tide å overlate ordet til Wergeland selv.

\section{Litteratur}

G jertsen F. Selvmord i N orge. H ovedfagsoppgave i sosiologi. 0 slo: U niversitetet i O slo, Institutt for sosiologi, 1987.

M ortensen ES. Eilert Sundt som selvmordsforsker. Suicidologi 1998; 3 (1): 4-7.

W ergeland $\mathrm{H}$. Selvmord. For A rbeidersklassen 1840; 1 (7. sept.)

U stvedt Y. H enrik W ergeland. En biografi. O slo: G yldendal, 1994.

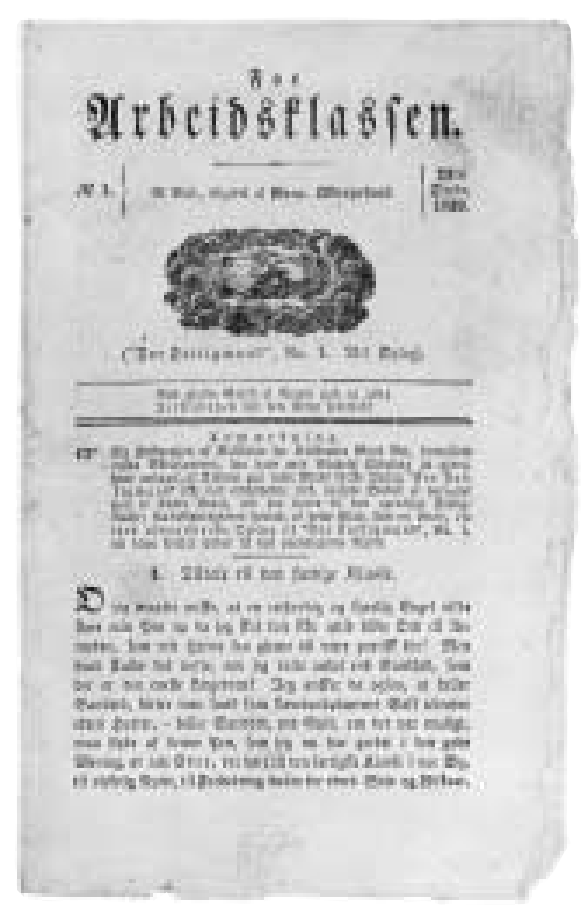

